\title{
Integrating Islamic Education Values to Build Religious Character of Student in Higher Education
}

\author{
Khoirul Anam $^{1}$ and Bagus Wahyu Setyawan ${ }^{2}$ \\ \{chasna.choir@gmail.com¹, bagusws93@gmail.com²\} \\ ${ }^{1}$ Faculty of Education and Teacher Training, Institut Agama Islam Negeri Tulungagung, \\ Indonesia \\ ${ }^{2}$ Universitas Sebelas Maret, Surakarta, Indonesia
}

\begin{abstract}
Islamic education is urgent to be applied and implemented in higher educations, especially the one under Ministry of Religious Affairs. It is because of many graduates or students still do not know and apply the Islamic education concept. This study aims to describe and explain the Islamic education concept in Islamic higher educations in Indonesia to construct the student religion character. It was a case study conducted in four Islamic higher educations, namely IAIN Tulungangug, IAIN Ponogoro, IAIN Surakarta, and IAIN Salatiga. The data were obtained by analyzing some institution activities and programs, institution visions, student activities, and student perceptions. They were then analyzed with using interactive analysis technique to identify research problems. The result shows that from vision and mission, the four higher educations have proposed the similar concept, namely developing human resource who have the Islamic character. Besides, programs and facilities provided to achieve vision are building the Student Activity Unit (UKM) that concern on developing Islamic science, building some student center research, and conducting Ma'had Al Jami'ah program. Moreover, the internalization of Islamic education values is also carried out in learning process by lecturers and educators in higher educations to create a religious culture among students.
\end{abstract}

Keywords: integration, Islamic education values, student religious character, Islamic higher education

\section{INTRODUCTION}

Education is basically an effort to guide, to direct, and to give someone a lesson in order to become better. In another word, the main goal of education is to construct good individuals in all aspects, namely cognitive, affective, and psychomotor [1]. Islamic education has more specific and comprehensive goal. It is not only to transfer science but also to prepare young generation become the ones who have spiritual and religious values. It becomes urgent and extremely important to do, considering many violations committed by students in some higher educations, such as brawls, harassments, free sex, thefts, violence, and extremist thoughts. This is due to the entry of secular and liberal concepts as well as lack of control from educational 
institutions [2]. Consequently, the Islamic education in academic society needs to be conducted and intensified to cope with those problems.

The Islamic education is conducted by internalizing and reinforcing Islamic values on academic society, especially students to build the religious character. The internalization of Islamic values not only focuses on the class hour. This has been accounted by Islmail and Ibrahim [3] that internalizing Islamic values is both conducted in the class hour and consistently and intensively conducted out of the class hour. Hence, a good cooperation is required among educators, parents, and students. The role of stakeholder in the educational institutions is also needed in order to take policies supporting the internalization process of Islamic values on academic society [4]. A study on the Islamic education is not only carried out in educational institution in Indonesia but also in some European countries. It was massively conducted in some educational institutions to cope with terrorism and secularity issues [5] [6]. In China, Islamic education aims to build humanist individuals and to differentiate ethnicities and races [7]. Those studies are used as references in this study to describe the Islamic education in higher educations in Indonesia, especially the Islamic ones.

The integration of Islamic values is truly important to prevent and to overcome problems related to academic society. The internalization of Islamic education values in education institutions for academic society needs to be intensified, so academic society are able to understand and to apply them in each academic and non-academic activities in higher education [8]. The efforts of educational institution in internalizing Islamic education values in academic society, especially students, are very urgent to do. They are activities, rules, and habits in the class by creating a religious atmosphere in those educational institutions. Religious activities and practices routinely conducted in a program is expectedly able to transform and internalize Islamic education values perfectly among students [9]. Hence, a program implemented to integrate Islamic education values aims to construct religious character among academic society, especially students. This program not only is limited in academic activities (learning activity) in the campus, but also include non-academic ones in the student activity unit, routinized studies, student forums, and routine activities related to religion problems out of the class hour to create a positive habit with the Islamic atmosphere among academic society. In particular, Internalization of Islamic education values obtained from the Quran and Sunnah are the soul of Islamic education institutions. Thus, educational ways and forms should develop and make student aware on Islamic education values.

\section{METHOD}

This study was descriptive qualitative with using case study approach. Case study was conducted in many state higher educations with the Islamic focus, namely Institut Agama Islam Negeri Tulungagung, Institut Agama Islam Negeri Surakarta, Institut Agama Islam Negeri Salatiga, and Institut Agama Islam Negeri Ponorogo. It aims to know how to internalize Islamic education values in building religious character among students. Source of data were 1) informants, including students, lecturers, and educational staffs, 2) events, in terms of learning process and student activities, and 3) documents, obtained from some curricula drafts, list of subjects, and some modules used by students. Data were collected through in-depth interview, field observation, and literature study from some documents. Research stages were based on Ledford \& Gast including preparation, instrument arrangement, field observation, and report of stages [10]. Data analysis utilized the educational data mining interactive analysis technique, in terms of prediction, clustering, relationship mining, discovery with models, and separation of data for human judgment to analyze data. 


\section{RESULT AND DISCUSSION}

Islamic education discussed in this study is related to the Islamic education implemented in some higher educations, especially those under the Ministry of Religious Affairs, namely Institut Agama Islam Negeri Tulungagung, Institut Agama Islam Negeri Ponorogo, Institut Agama Islam Negeri Surakarta, and Institut Agama Islam Negeri Salatiga. Each institution and higher education have typical characteristic in conducting the educational processes. This is because of their different visions.

Firstly, Institut Agama Islam Negeri Tulungagung has a vision "Terbentuknya masyarakat akademik yang berlandaskan prinsip-prinsip ilmu pengetahuan, berakhlaq karimah, dan berjiwa Islam rohmatan lil'alamin" (Constructed the academic community based on science, akhlaq karimah, Islam rohmatan lil'alamin soul principles). This vision indicates that IAIN Tulungagung focuses on academic activities to build the academic community who have knowledge and religious character. All academic society in IAIN Tulungagung are expected to have the religious character based on Islamic religion principles.

Besides, vision of Institut Agama Islam Negeri Ponorogo is "Sebagai Pusat Kajian Dan Pengembangan Ilmu Keislaman Yang Unggul Dalam Rangka Mewujudkan Masyarakat Madani" (As the Excellent center of Islamic Study and Islamic Science Development to Achieve Civil Society). This vision clearly represents that IAN Ponorogo attempts to become a place for every activity related to Islamic studies and Islamic science developments. It is reflected by a number of student activities focusing on the development of Islamic sciences. Besides, educators and lecturers in IAIN Ponorogo are also provided facilities in terms of Academic Journals for disseminating their research results. These journals mostly have been accredited by the Ministry of Research, Technology and Higher Education with good predicates. These reflect that IAIN Ponorogo becomes the center for Islamic studies and Islamic science developments. Student activities, lecturer research activities, and scientific article publications of both lecturers and students become the standard for the success of academic activities in higher education [11].

Different from IAIN Ponorogo, Institut Agama Islam Negeri Surakarta has more global and wider point of view. It is reflected by its vision, namely "Menjadi World Class Islamic University di level Asia dalam kajian sains yang terintegrasi dengan kearifan lokal pada 2035 " (Becoming the World Class Islamic University in the Asian Level on Local Wisdom-integrated Science Studies in 2035). It implies that IAIN Surakarta is a forward-looking institution among Asian, especially in sciences and local wisdoms. Hence, the active and productive student activities involve sciences, writing, and student creativity programs. In terms of publication, this institution also provides some publication facilities, namely student bulletins, journals, and books with the HAKI certification.

In addition, Institut Agama Islam Negeri Salatiga has a quite similar vision with IAIN Surakarta in terms of the global knowledge. IAIN Salatiga vision is "Tahun 2030 Menjadi Rujukan Studi Islam-Indonesia bagi Terwujudnya Masyarakat Damai Bermartabat" (Becoming the reference of Islamic-Indonesian Studies to Achieve the Dignified Peaceful Society in 2030). A concept developed by IAIN Salatiga is Islamic-Indonesian that is an Islamic point of view based on life principles embraced in Indonesia. This concept is known as Islam Nusantara, which is contextual and does not leave indigenous tradition-culture.

Considering those visions, most of them have the same perspective that is to develop Islamic studies and Islamic knowledges among academic society. Developing Islamic sciences involves academic and non-academic fields to build the religious character among students [12]. 
Consequently, activities of integrating Islamic values among students academically and nonacademically are needed. They are conducted in and out of the class hour. Activities out of the class hour are Student Activity Unit, Student Center Research, and Campus Ma'had Activity or Pesantren Mahasiswa (Student Boarding Area).

\subsection{Facilities to Build and Develop Islamic Character among Students}

To develop Islamic character among academic society, the higher education provides several facilities and programs. Regarding the vision of Islamic higher educations, they focus on develop and conduct Islamic educations. Facilities to develop this Islamic character are divided into three, namely resource developments, physical facilities, and programmed activities. Programmed activities have been included into curriculum and learning units, such as praying before and after studying, reading the Quran in learning process, habituating to follow Islamic adzab and rules, and so forth.

Physical facilities to build and develop Islamic character among students are library with complete facilities, discussion room for students, and Ma'had or Pesantren Mahasiswa (Student Boarding Unit). The program of resource development can be done by optimizing the Student Activity Unit (UKM) and student center research.

\subsubsection{Student Activity Unit (UKM)}

Student Activity Unit (UKM) is a forum for student activities out of the class hour. It aims to develop certain interests, talents and expertise. In higher educations, there are several types of UKM, varied appropriate to the level of student needs. Activities in UKM mostly focus on the development of student interests and talents in terms of sports, arts, organizations, and religions [13]. In particular, Islamic higher educations, such as IAIN Tulungagung, IAIN Ponorogo, IAIN Surakarta, and IAIN Salatiga have some UKM frequently focusing on the development of interests and talents in terms of Islam. This clearly refers to the vision of each higher education.

The Student Activity Unit (UKM) in IAIN Ponorogo include Islamic Activity Unit (UKI) Ulin Nuha engaging Islamic fields, such as conducting Islamic studies, shalawat, contemporary discussion on religious sciences, and so forth. Its function is to facilitate students with the concentration of developing their interests and talents in religious fields. In IAIN Surakarta, there is UKM focusing on missionary endeavor, namely Campus Missionary Institution (LDK) Nurul Ilmi. This UKM engages to discuss contemporary Islamic issues, to discuss Islamic knowledge from some perspectives, and to train students to be able to develop themselves in missionary endeavor field or as a missionary.

The UKM activities attended by students train them to actualize themselves so that they have qualified soft skills, both in academic and religious aspects. Activities in the UKM train students to be able to work together and to cooperate with their fellows [14]. Tolerance, respect other opinions, braveness to argue, and religious characters are definitely developed by following each process and activity in the UKM. Besides, the concept of deliberation and consensus is always used to make a certain decision by UKM members. Some of these characters are obtained by students who are active in every UKM activity. They not only have to be serious, but also should have strong intention and willingness to be able to gain experience and knowledge from UKM activities.

\subsubsection{Student Center Research}

Some higher educations also organize a program or forum for students who have talents and interests in a particular field. This is accommodated in a student center research or kind of 
discussion forum for discussing certain themes. The study center in Islamic higher educations naturally involves the religious sciences. At IAIN Tulungagung, there is a Javanese Islamic study center that focuses on studying the variations of Javanese Islam. The mission of the Javanese Islamic Study center is to conduct researches on Javanese Islam which are then published in books and scientific journals or presented in seminars. In the Javanese Islamic study center, students are directed to be able to know history, upheaval, development, and synthesis of several traditions in Javanese Islam studies.

Institut Agama Islam Negeri (IAIN) Salatiga has also a study center concentrating in gender and children. It focuses on discussing gender and children issues from Islam point of view. Students are also required to have a critical mindset so that have sensitivity on contemporary issues and the development of science. Since students have critical and analytical thoughts, students must to think rationally in finding solutions of each problem [15]. Consequently, students become more curios and then will continue to look for as well as to seek the information for their self-development. The study center plays a role in educating students to have progressive thinking in developing sciences, especially the Islamic one [16]. Henceforth, higher education institutions, as one of facility to create millennial generation religious leaders will surely be able to realize the concept of civil society.

\subsubsection{Ma'had Al Jami'ah}

Ma'had is an institution that accommodates some student activity. In some Islamic higher educations, such as in IAIN Tulunagung, IAIN Ponorogo, IAIN Surakarta, and IAIN Salatiga have almost the same concept as pesantren (boarding educational institution), namely trying to educate students in a religious environment within two semesters to form the character akhaqul karimah among students. The mission and main purpose of Ma'had Al Jami'ah is to make students have the stability of aqeedah (belief), moral glory and the breadth of religious knowledge, and to train their reading comprehension skill in the Quran and Arabic speaking skill.

There are several programs proposed by Ma'had Al Jami'ah in order to build religious character among students. The programs in pesantren or boarding educational institution are divided into daily programs, weekly programs, monthly programs, and annually programs [17]. As found in Ma'had Al Jami'ah Ulil Abshar at IAIN Ponorogo, it has several programs, including daily programs (Shubbah al Lugah, Ta'lim al Lugah, Ta'lim a Qur'an, tartil, Tahfidz of short Surah, Ta'lim al Kitab, Istigatsah, praying in congregation, and short Islamic lecture), weekly programs (Yassin and Tahlil, mutual work of cleaning certain places in every Friday, language day, and ta'lim musrif), monthly programs (meeting, evaluation, khatmil Quran, Ta'limul 'asr, Muhadloroh, and Diba'an), as well as annual programs (new student orientation, Last Haflah as Sanah, Rihlah and pilgrimage tourism to Wali, PHBI dan PHBRI, art performances, Ma'had test, Ramadhan boarding, comparative study, and meeting). These programs implemented in Ma'had Al Jami'ah will indirectly build the religious character among students, because students are trained and cultivated with activities to construct their spirituality [18].

\subsection{Implementation Process of Islamic Education Value among Students}

After the program and system were constructed to build the religious character among students, its implementation is then conducted. Islamic education values are implemented not only in curricular activities in the campus, but also in co-curricular and extra-curricular activities. This intentionally makes the education system more effective and optimized in Islamic higher education [19]. Hence, the output or graduates become truly excellent and have 
moral characters. There are several steps that must be done to implement Islamic education values in educational process. Each stage has a different level of difficulty.

The implementation of Islamic educational values among students can be carried out by using some methods. The internalization process related to managing students contain three stages as the followings.

\section{- Transformation of Values}

This stage is a process conducted by educators in transforming good and bad values. In this stage, there is only verbal communication occurring between educations and students. Educators or lecturers give students understanding and information through some real examples about educational values in Islam, such as tolerance, good manner, respect, helping each other, and so forth. It is used to give students stimulus, so they know the concept of Islamic education implemented in their daily life.

\section{- Transaction of Values}

This stage is a value education stage through two-way communication. In this stage, students have the opportunity to do discussion and questions and answers with lecturers on the concept of Islamic education values. It is objected to obtain the understanding about Islamic education concept between lecturers and students. Lecturers should definitely be able to direct student mindset and point of view about the concept of Islamic education values. Besides, students are also prevented to have a deviant understanding on the concept of Islamic education values.

\section{- Trans-internalization}

This stage is deeper than transaction. In this stage, students are not only encouraged to do verbal communication but also to improve their mental and characteristics. Besides, Communication actively gives contribution to conduct this stage. Students become accustomed to take action appropriate to the concept of Islamic education values as compromised before. This aims to build a positive culture among students so that can firmly hold Islamic education concept in daily life [20][21].

\section{CONCLUSION}

Higher education are institutions to create young generation who have knowledge and good soft skills. Besides, Islamic higher educations must be able to apply and internalize the concept of Islamic education values for students. This has to be done in several programs, namely the development of human resource, physical facilities, and routine activities necessarily conducted by students. In the class, lecturers are also demanded to be able to implement Islamic education values in front of students. After the concept of Islamic education values can be internalized perfectly among students, a good learning culture will be reflected. The outputs truly have good manner that can bring Islam to and develop Islam in society.

\section{REFERENCES}

[1]. M. Yunus. "Development of the Model of Character Education at the Islamic Boarding School in Watangpone". Journal of Research and Multidisciplinary, Vol. 1, No. 1, pp. 110, 2018.

[2]. U. Papen. "Hymns, Prayers, and Bible Stories: The Role of Religious Literacy Practices in Children's Literacy Learning". Ethnography and Education, Vol. 13, No. 1, pp. 119134, 2018. 
[3]. R. Ismail and R. Ibrahim. "Teachers' Perception on Digital Game: A Preliminary Investigation towards Educational Game Application for Islamic Religious Primary Schools", Proceeding 2018 International Conference on Information and Communication Technology for the Muslim World (ICT4M), pp. 36-41, 2018.

[4]. I. Rissanen and Y. Sai. "A Comparative Study of How Social Cohesion is Taught in Islamic Religious Education in Finland and Ireland", British Journal of Religious Education, Vol. 40, No. 3, pp. 337-347, 2018.

[5]. Z. Çitak. "National Conceptions, Transnational Solidarities: Turkey, Islam, and Europe", Global Networks, Vol. 18, No. 3, pp. 377-398, 2018.

[6]. A. Sahin. "Critical issues in Islamic education studies: Rethinking Islamic and Western liberal secular values of education", Religions, Vol. 9, No. 11, pp. 335, 2018.

[7]. H. H. Basri, "The Mosque Based Islamic Education in Guangzhou China", UMRANInternational Journal of Islamic and Civilizational Studies, Vol. 5, No. 2-1, 2018.

[8]. F. Anwar, R. Rahman, and Z. Zein. The Implementation of Teaching and Learning Process of Islamic Study in Universities in Indonesia. Khalifa Journal of Islamic Education, 1(1), 15-30.

[9]. C. Tan and A. Ibrahim. "Humanism, Islamic Education, and Confucian Education." Religious Education, Vol. 112, No. 4, pp. 394-406, 2017.

[10]. J. R. Ledford and D. L. Gast. Single Case Research Methodology: Applications in Special Education and Behavioral Sciences. British: Routledge, 2018.

[11]. J. T. Avella, M. Kebritchi, S. G. Nunn, and T. Kanai. "Learning Analytics Methods, Benefits, and Challenges in Higher Education: A Systematic Literature Review" Online Learning, Vol. 20, No. 2, pp. 13-29, 2016.

[12]. F. Shehu. "The Role of Inter-Religious Dialogue in Promoting Islamic Education to the Europeans", Learning, Vol. 62, pp. 396, 2016.

[13]. M. Mustafa, V. R. Naidu, Q. A. Mohammed, K. A. Jesrani, R. Hasan, and G. Al Hadrami. "A Framework for Collaborative and Active Learning for Enhancing Student Engagement”. International E-Journal of Advances in Education, Vol. 5, No. 13, pp. 8393, 2019.

[14]. S. Tharayil, M. Borrego, M. Prince, K. A. Nguyen, P. Shekhar, C. J. Finelli, and C. Waters. "Strategies to Mitigate Student Resistance to Active Learning". International journal of STEM Education, Vol. 5, No. 1, pp. 7, 2018.

[15]. A. Setiawan, A. Malik, A. Suhandi, and A. Permanasari. "Effect of Higher Order Thinking Laboratory on the Improvement of Critical and Creative Thinking Skills" IOP Conference Series: Materials Science and Engineering, Vol. 306, No. 1, pp. 012008, 2018.

[16]. I. P. Ahmad. "Islamic Ethics for Sustainable Development and Developing Social Conscience: An Islamic Response to the Challenge of Ecology Today" Al-Itqan: Journal of Islamic Sciences and Comparative Studies, Vol. 1, No. 1, pp. 49-61, 2018.

[17]. D. T. Wirawan. "Social Accountability Process of Islamic Boarding School: Case Study of Sidogiri Pasuruan Islamic Boarding School.” International Journal of Multicultural and Multireligious Understanding, Vol. 6, No. 1, pp. 134-158, 2019.

[18]. M. Y. Salam and S. Suharmon. "The Implementation of Ma'had Al-Jami'h Curriculum in Improving the Ability of Arabic Language in UIN Maulana Malik Ibrahim Malang". PROCEEDING IAIN Batusangkar, Vol. 3, No. 1, pp. 207-214, 2019.

[19]. J. Paramboor and M. B. Ibrahim. "Islamic Higher Educational Institutions in a Secular Country: South Indian Lessons of Systemic Survival", Islamic Insight, Vol. 1, No. 1, pp. 103-123, 2018. 
[20]. B. Suryadi, F. Ekayanti, and E. Amalia. "An Integrated Curriculum at an Islamic University: Perceptions of Students and Lecturers" Eurasian Journal of Educational Research, Vol. 18, No. 74, pp. 25-40, 2018.

[21]. K. Saddhono, "Integrating Culture in Indonesian Languge Learning for Foreign Speakers at Indonesian Universities." J. of Lang. and Lit. vol. 6 no.2 pp. 349-353, 2015 